\title{
Foundling and Abandoned Children in Palestine
}

\author{
Bassam Yousef Ibrahim Banat ${ }^{1}$, Sameer Shqair ${ }^{2} \&$ Iskandar Andon $^{3}$ \\ ${ }^{1}$ Department of Applied Sociology, Al-Quds University, Jerusalem- Abu Dies, Palestine \\ ${ }^{2}$ Department of Psychology, Al-Quds University, Jerusalem- Abu Dies, Palestine \\ ${ }^{3}$ Crèche Institution, Bethlehem, Palestine \\ Correspondence: Bassam Yousef Ibrahim Banat, Department of Applied Sociology, Faculty of Arts, Al-Quds \\ University, Main Campus, Jerusalem- Abu Dies, Palestine. Tel: 970-2252-2727. E-mail: bbanat@staff.alquds.edu \\ orbassambanat@yahoo.com
}

Received: August 13, 2019 Accepted: September 1, 2019 Online Published: September 13, 2019

doi:10.5539/gjhs.v11n11p52 URL: https://doi.org/10.5539/gjhs.v11n11p52

\begin{abstract}
The study addressed foundling and abandoned children in the Palestinian society as a multi-dimensional phenomenon. The study consisted of a retrospective transversal survey of one hundred and fifteen abandoned children, and ninety-two abandoning mothers purposefully selected from the records of Crèche Institution in Bethlehem, West Bank. The findings indicated that the ratio of foundling and abandoned children in the Palestinian society is very low comparison with international figures. The study concludes that child abandonment in the Palestinian society is a risk factor, and that under-reporting of offences, especially incest is widespread in the Palestinian patriarchal society.
\end{abstract}

Keywords: Abandoned children, incest, foundling children, adoption, patriarchal society

\section{Introduction}

Child abandonment still remains a largely hidden problem in most countries worldwide. Abandonment occurs when a mother physically, emotionally or psychologically withdraws from her children. She does this by ignoring her responsibility to parent her children, or ending her relationship with her children (Van Wyden, 2014).

The concept of child abandonment has been a key of debate in both historical and ethnographic studies (Panter-Brick \& Smith, 2000). The phenomenon of abandoned children has been documented as early as 1848 by Alan Ball, in the introduction to his book on the history of abandoned children: "And now my soul is hardened: abandoned children in Soviet Russia, 1918-1930", which reports that orphaned and abandoned children have been a source of misery since the earliest times (Ball, 1994; Boswell, 1998).

In 1848, Lord Ashley referred to more than 30,000 naked, filthy, roaming lawless and deserted children in and around London (Del Col, 1988). By 1922 there were at least seven million homeless children in Russia because of the devastation caused by the World War I and the Russian Civil War (Ball, 1994).

Abandonment also refers to the voluntary dismissal of control over children by their parents or guardians, leaving them somewhere, selling them, or legally consigning authority to another person or institution (Boswell, 1998; Kgole, 2007).

Article seven of the United Nations Convention on the Rights of the Child (CRC) states that every child has the right to know and be cared for by his or her parents. When a child is abandoned, this right is violated. Infants and young children are at a great risk of being abandoned (UN, 1989; The University of Nottingham, 2012).

According to UNICEF estimates, millions of abandoned children live in several cities around the world, with a large number residing in Latin America, Western Europe and Africa (International Street Kids, 2014).

\section{Background and Literature Review}

Abandon is a way to give up a person or something or a place that has no intention of returning (Kgole, 2007). Abandoned children are considered a very flexible opinion that has long been used to prove claims about victim status and compensation for empathy and care (Ransel, 2002).

Child abandonment is a global phenomenon that has occurred to varying degrees in almost every culture and society. The main difference is how and why children are abandoned and what happens to them, which is 
dependent on the specific time, place, and culture (Fuchs \& McBride-Schreiner, 2014).

Historically, mass child abandonment around the world and through generations since the early $1600 \mathrm{~s}$, has been reported usually associated with urbanization and other related social problems such as broken family support systems, young single women's vulnerability in these environments, and the devastating impact of poverty (Blackie, 2014).

Between the $17^{\text {th }}$ and $18^{\text {th }}$ centuries, Europe witnessed a staggering rise in child abandonment rates and the creation of the first houses for the capture and founding of scorpions, led mainly by spiritual institutions such as the Catholic Church. In the 19th century, the United States experienced a similar rise due to industrialization and migrant labor. However, they lacked the social support systems in Europe with devastating consequences for children. Moreover, in the late 1980s, there was a significant increase in child exemption in China, which coincided with governments recently implementing a strict policy on one child per family (Fuchs \& McBride-Schreiner, 2014).

Article 27 of the Convention on the Rights of the Child (CRC) confirms that states parties recognize the right of every child to an adequate standard of living for the child's physical, mental, spiritual, moral and social development (UN, 1989). Abandoned children are naturally denied of these rights.

The operational definition of the term "abandoned child" refers to a child whose biological parents have stated their responsibility to care for and meet their basic developmental needs and who have physically separated themselves from them before assuming this responsibility by an authorized institution (Stativă et al., 2005).

Furthermore, UNICEF defined the abandoned child as a child who does not know where his next meal will come from; he or she does not know where to spend the night; he or she does not live with a mother or father. However, International Street Kinds-ISK (2014) reports the following set of statistics: every two seconds the child becomes an orphan; every 14 seconds the child is orphaned with AIDS; authorities estimate that child pornography is $\$ 20$ billion a year; many abandoned children end up as victims of this deviant activity; many street children use a number of inhalants (glue, gasoline, lighter fluid) and illegal drugs (marijuana, cocaine and heroin); and abandoned children are routinely detained illegally, beaten and tortured and sometimes killed by police in some countries.

In short, abandonment includes physical and emotional issues. On the one hand and in some cases, abandonment is physical. Physical abandonment occurs when physical conditions of prosperity are replaced by lack of proper supervision, inadequate nutrition and meals, inadequate clothing, housing, heat, shelter, physical and/or sexual abuse (Black, 2010). On the other hand, emotional neglect occurs when parents fail to provide the emotional conditions and emotional environment necessary for healthy growth. Additionally, Kgole (2007) points out that abandonment can include child abuse, emotional abuse, and neglect.

Abandoned children are found in a large majority of the world's cheif cities, with the phenomenon spread in densely populated urban centers in developing countries or economically unstable areas. According to the United Nations, millions of street children live in various cities around the world, with a large proportion living in South Africa, Eastern Europe, South Asia and Latin America (Huang et al., 2004).

In fact, the hidden and isolated nature of abandoned children makes it difficult to collect accurate statistics. Rough estimates of UNICEF show that the number of abandoned children is increasing. More than 400 million abandoned children live alone in the streets of hundreds of cities around the world; and they are struggling to survive the day (International Street Kids, 2014).

To sum up, one of the biggest challenges facing the world today is the phenomenon of foundling children. It is considered an overwhelming social problem in all rich and poor countries. This phenomenon has existed since ancient times; therefore, world countries in general and Arab countries in particular, have dedicated special attention to this phenomenon. This has actually taken place following the signing of the international child conventions and after a noticeable increase in the number of foundlings deposited right at the doorsteps of churches or mosques, hospitals, parks and open veldts, cemeteries or even rubbish sites. As a point of fact, this has turned into a phenomenon that is threatening some Arab countries.

In the Arab countries, it is rather difficult to measure the exact number of abandoned children due to the notion of social stigma in the Arab culture, and consequently many of which are under-reported. The number is nonetheless large and growing almost certainly with the phenomenon of incest, which increases the figures of foundling children in the Arab societies (Al-Watan Voice, 2012). NGOs estimated that at least thousands of abandoned children in the Arab world, most in the countries of Morocco, Sudan and Egypt (Al-Watan Voice, 2012). 
Similarly, there are no official statistics about abandoned children in the Palestinian society, according to the authors' knowledge. Crèche Institution in the holy city of Bethlehem, the cradle of Jesus Christ, is the only pioneer institution, which is engaged in the field of providing protection and care for foundling children in Palestine. This institution was established in 1883, and it offers services to more than two hundred children up-to-date; it is the only secure shelter for women in distress as well as for pregnant women outside the legitimacy of legal marriage; pre- and post-natal care is given to these mothers in order to secure their safety and that of their newly born child.

Although child abandonment is a global phenomenon, it has not been sufficiently studied or understood thus far (Fuchs \& McBride-Schreiner, 2014). Nelson et al. (2014) concluded that Romania's abandoned children document the devastating toll that children pay for deprived responsive care, social interaction, motivation and psychological comfort.

Furthermore, Van Weiden (2014) concluded that a child who lost his mother to abandonment suffered from grief and confusion when hearing his friends talk about their mothers because it was difficult for him/her to see other children living a normal life in a healthy family. Moreover, the study of Blackie (2014) indicated that child abandonment is increasingly associated with post-traumatic stress for both the abandoned mother and the abandoned child.

Additionally, a study by Black (2010) found that when children suffer from chronic loss without the psychological or physical protection they need and certainly deserve, it is extremely natural for them to absorb the incredible fear; not receiving the necessary psychological or physical protection equals abandonment; and living with repeated abandonment experiences creates toxic shame. Meanwhile, Whetten et al. (2009) argued that leaders struggle to care for an estimated 143 million orphans and millions of abandoned children worldwide; and global decision makers are advocating for the swiftest transfer of orphaned children living in abandoned institutions and children $(\mathrm{OAC})$ to a family home and care environment, and that institutional care shall be a last resort.

Overall, many governments, NGOs and members of civil society around the world have shown interest in abandoned children because the number has increased dramatically. Despite that, more work is needed.

\section{Aims and Scope}

Banter Brick Smith (2000) argued that the situation of abandoned children's attracts a lot of political and tabloid interest, but it is somewhat surprising to sociologists worldwide. This is the first study, to the author's knowledge, which examined the extent of foundling and abandoned children in the Palestinian society, which is considered a taboo. This study also included an understanding of the prevalence of child abandonment, the consequences of abandonment, and the possible reasons behind this multi-faceted phenomenon to fill an important gap in the knowledge about foundling and abandoned children in the Palestinian society. A measure of the study topic is presented with demographic variables related to abandoned children and abandoning mothers. The study applications are essential as a reference point for evaluating possible effective prevention programs and social policies for intervention aimed at protecting the most vulnerable children and mothers in the patriarchal Palestinian society.

\section{Questions}

The study addressed the following questions:

4.1 What are the main demographic characteristics related to foundling and abandoned children in the Palestinian society?

4.2 What are the main demographic characteristics related to abandoning mothers in the Palestinian society?

\section{Methodology}

\subsection{Approach}

A retrospective transversal study was conducted over a period of seven months in 2017 to carry out the study objectives.

\subsection{Population and Sampling}

The study population constituted of foundling and abandoned children at Crèche Institution in Bethlehem, West Bank in the years between 1999 and 2017 temporarily or definitely abandoned, and their mothers based on the primary data of Crèche Institution. The sample survey constitutes one hundred and fifteen foundling and abandoned children and ninety-two abandoning mothers purposefully selected (Crèche Institution, 2017). 


\subsection{Instrumentation}

This study is quantitative in nature using a questionnaire developed by the authors. The sample survey involved studying the records of the foundling and abandoned children and the available evidence of their mothers. Data was collected between June and November in 2017. The questionnaire consisted of two main sub-scales: the first contained the background information of foundling and abandoned children, which included, gender, age, year of abandonment, site of abandonment, time of abandonment, region of abandonment, type of abandonment, the health situation, and adoption status. The other contained information of abandoning mothers which included, age, marital status, level of education, residence, health and economic situation.

\subsubsection{Validity}

Validation of the instrument proceeded in two distinct phases. The initial phase involved a group of referees and experts, while the second phase involved a small focus group session of eighteen children to validate the survey. Both measures indicated that those items were suitable in measuring every item of the multi-dimensional phenomenon of child abandonment among the sampled population.

\subsection{Data Analysis}

The questionnaire items were ranked and codified in order to carry out the required statistical analysis of the data. Descriptive statistics were generated to evaluate the rate of child abandonment among the sampled population by measuring: frequencies, percentages, mean scores, standard deviation and graphics using SPSS.

\section{Findings}

One hundred and fifteen abandoned children and ninety-two abandoning mothers were investigated. The ratio of child abandonment in the Palestinian society is shown to be very low (0.03\%) in the years between 1999 and 2017, which is translated to an estimated number of 125 children in 19 years out of 362032 estimated births between 1999 and 2017 (Palestinian Central Bureau of Statistics, 2017).

Contextual demographic variables of children included gender, age, year of abandonment, site of abandonment, time of abandonment, region of abandonment, type of abandonment, health situation, and adoption status. Boys represented $52.2 \%$ of the children while the remaining $47.8 \%$ were girls. In terms of the age of abandoned children, most of the child abandonment was at the age of one day (54.8\%), followed by the age of $2-5$ days $(24.3 \%$ of the children). The number of abandoned children seems to decrease as the age increases.

Furthermore, the study findings reveal that child abandonment in the Palestinian society took place over the years starting from 1999 until 2014, mostly in the year 2000 (12.2\%), followed by $2008(11.3 \%)$ and $9.6 \%$ in the year 2012. As for the registered site of abandonment, it was on the doorstep of a church or a mosque $(23.5 \%)$, rubbish sites, dustbins and landfills (18.3\%), parks and open veldts (16.5\%), hospitals (14.8\%), and in other sites mostly at Crèche, sewers, and on the street respectively and ranked in a descending order.

Additionally, results indicated that concerning the time of abandonment, the majority of abandoned children was during the night hours (55.6\%); and 52.2\% of those were abandoned in the South of Palestine. In terms of abandonment type, the vast majority was classified as "illegal child" (80\%) from out of wedlock, due to different reasons mostly marriage promise $(40.2 \%)$, family incest $(32.6 \%)$, prostitution $(21.7 \%)$ and rape $(5.4 \%)$.

Of the sample population, $22.6 \%$ of the children had congenital malformations; $53.8 \%$ of which were temporarily compared to $46.2 \%$ permanently. An analysis of the child's route showed that the vast majority $(82.6 \%)$ of children had been discharged form Crèche Institution, more than half of whom (57.4\%) were in adoption programs, specifically $(77.3 \%)$ inside Palestine.

With regards to abandoning mothers, contextual demographic variables included age, marital status, level of education, residential environment, health and economic situation. An analysis of the characteristics of mothers who had abandoned their children revealed that $44.6 \%$ were less than twenty years of age at the time the child was born, while $33.7 \%$ were in the age of $20-30$; the majority of them were single $(71.7 \%)$; and the vast majority of them (80.4\%) did not complete Junior School.

Moreover, the residential environment of mothers did not show a significant statistical difference between urban and rural areas of abandoned children in the Palestinian society: $42.4 \%$ of whom lived in rural villages, $40.2 \%$ from urban cities, $13 \%$ were refugee camps residents, and $4.3 \%$ were from Bedouin communities. As for the health situation of the mothers, the study showed that $78.3 \%$ of them were considerably healthy, while the remainder were disabled; where $55 \%$ are temporarily disabled compared to $45 \%$ permanently disabled. Finally, the study revealed that $79.3 \%$ of mothers were below the socio-economic level. 


\section{Discussion}

The study findings indicated that the ratio of child abandonment in the Palestinian society is very low comparison with international figures. Despite the drop in the average of foundling children in the Palestinian society compared with international figures including Middle Eastern countries, the outcomes are very alarming especially when living in a conservative society that strictly adheres to religious and moral values.

In fact, child abandonment in the Palestinian society is a risk factor, and that under-reporting of offences, especially incest is widespread in a patriarchal ideology that is deeply rooted in the Palestinian society. The subject is taboo in a male-oriented culture of denial (Barakat, 1993; Arab Human Development Report, 2009; Banat, 2014).

Child abandonment is a complex problem that represents not only serious difficulties for the overburdened child and mother, but also for the society. According to Black (2010), experiences of abandonment and violating boundaries in no way constitute charges for the child and the child's innate values, they instead reveal the misunderstanding, misconception and bad behaviors to those who harm them. However, wounds are deep in their young hearts and minds, and this very real pain continues today and will remain with them and become a driving force in their adult lives. Similarly, Panter-Brick and Smith (2000) concluded that neglect isolates abandoned children from their peers, assumes that they are more vulnerable, and implies an irreversible change in home relationships.

Meanwhile, abandoning mothers often find themselves in desperate situations mostly frustrated with feelings of disempowerment, anger and depression in a patriarchal society who tends to blame the victim. In this regard, the World Health Organization (2013) reported that violence against women is a public health problem with epidemic proportions because it spreads throughout the world, endangering women's health, limiting their participation in society and causing great suffering.

In short, the act of abandonment is a chronic social stigma starting from the birth event, which may lead to suicide, as documented with the abandoned Palestinian child F.B. from Crèche Institution when he discovered his abandonment reality after 21 years of age (Andon, 2014).

Moreover, the phenomenon of abandoned children poses a complex social challenge in the Palestinian Islamic society, specifically when it comes to adoption, which is frequently with sub-cultural barriers. Marriage is the only culturally and legally accepted way to regulate a family. The teachings of Islam call for a legal Shari'a marriage within the framework of matrimony in order to prevent any mixing of lineage. Any sexual relationships outside of marriage are considered taboo and a great sin, which leads to legal punishment. "And approach not adultery, undoubtedly that is immodesty and a very vile path" (Isra: 32 ).

Furthermore, it was also narrated that Prophet Mohammed - May God's peace and prayer be upon him - to have said, "O young men, whoever among you can afford it, let him get married, for it is more effective in lowering the gaze and guarding one's chastity. Whoever cannot afford it, let him fast, for it will diminish his desire." Similarly, Islam is very keen on taking care of foundling children in particular since they did not commit a sin to deserve this suffering and punishment. The Prophet called for providing guardianship for them since in Islam there is no adoption by making them sons, brothers or neighbors; he/she shall have what we have and he shall do the same duties like us (Idees, 2014). This confirms what is stated in the Holy verses, "Call them after their father's, this is more justified in the sight of Allah, but if you do not know their fathers, then they are your brothers in faith and as human being your cousin" (Ahzab: 5).

In terms of Muslim tolerance concerning foundling children and its wholehearted teachings in taking care of them, it was narrated that:

"There came to him (the Holy Prophet) a woman from Ghamid and said: Allah's Messenger, I have committed adultery, so purify me. The Holy Prophet turned her away after he knew that she was pregnant with an illegitimate child. He told her: go away until you give birth to (the child). When she delivered, she came with the child (wrapped) in a rag and said: Here is the child whom I have given birth to. She said: Allah prophet purify me from adultery. He looked at her child and said: Go away and suckle him until you wean him. When she had weaned him, she came to him (the Holy Prophet) with the child. He (the Holy Prophet) entrusted the child to one of the Muslims by saying whoever takes guardianship of this child will be my companion in paradise like these two fingers, and then pronounced punishment. And they stoned her. Afterwards the Prophet (PBUH) led her funeral prayers. And she was buried. 'Umar May God be pleased with said: "O Messenger of Allah! She committed Zina and you have performed funeral prayer for her?" He replied, "Verily, she made repentance which would suffice for seventy of the people of Al-Madinah if it is divided among them. Can there be any higher degree of repentance than that she 
sacrificed her life voluntarily to win the Pleasure of Allah" (Idees, 2014).

On the other hand, Christianity made adoption permissible. It is undoubtedly difficult to find a child without a father or a mother and so being with a family would help that child to put up with life's difficulties and to bestow upon him/her love and affection. It is also harder when those children are without a name or a family they could relate to. Their parents have committed a dreadful sin, the outcome of which is this child who is the forbidden fruit of momentarily pleasure and desire on one side, and a source of long years of sadness on the other side. Adoption would protect foundling children who would live in a natural family. In addition, the adoption of this child would bring happiness and joy to the lives of so many couples who are unable to have babies taking into consideration the Christians percent in the Palestinian society that do not exceed more than 1 percent of the Palestinians (Awwad, Abood Orthodox Church Priest, 2014).

Furthermore, Christianity preaches having a legal marriage and forbids any pre-marital coitus. Moreover, as part of the teachings of Jesus Christ, He called for tolerance:

"They say unto him, Master, this woman was taken in adultery, in the very act. Now Moses in the law commanded us, that such should be stoned: but what sayest thou? So when they continued asking him, he lifted up himself, and said unto them, He that is without sin among you, let him first cast a stone at her. And they which heard $i$, being convicted by their own conscience, went out one by one, beginning at the eldest, even unto the last: and Jesus was left alone, and the woman standing in the midst. When Jesus had lifted up himself, and saw none but the woman, he said unto her, Woman, where are those thine accusers? Hath no man condemned thee? She said, No man, Lord. And Jesus said unto her, neither do I condemn thee: go, and sin no more" (Verses 7:53-8:11 of the Gospel of John).

Although adoption may be one of the proposed solutions to the problem of foundling and abandoned children in the Palestinian society but it entails many risks. According to Stativă et al. (2005), separation of the child from his mother shortly after birth, or at a very young age, at a health institution exposes the child for long and significant periods to a presence in which his or her developmental needs are ignored.

\section{Conclusion and Recommendations}

Child abandonment is a global phenomenon that exists in modern societies more than the classical ones. Child abandonment has raised alarm bells among several Palestinian organizations taking into consideration the number of abandoned children born out of wedlock and incest, which is rather difficult to evaluate in the Palestinian society where the under-reporting of offences is widespread in a patriarchal system that jeopardizes the reputations of women in the community over their own well-being and lives. Much needs to be done concerning the delivery of children in relation to the needs of children and mothers in the Palestinian society, which has conservative customs and traditions, male patriarchal domination and gender inequality. In light of the study findings, the following recommendations are made:

1. Provide legal protection and social assistance for foundling and abandoned children and their mothers.

2. It is essential to establish close cooperation between all sectors of the society on the formal and civil levels with regards to social awareness in order to avoid an increase in the number of foundling children in the Palestinian society, to treat these children with dignity and to integrate them into society as normal individuals since they are victims of the sins of their parents and based on their right to lead a normal life as the rest of the children.

3. Families must assume the responsibility of social discipline and sound social upbringing of their children through sound guidance and monitoring of their behaviors reinforcing sexual health education in the school curriculum to raise awareness.

4. Empowering women in the Palestinian society is an essential component for the prevention of violence and prejudice against them.

\section{Competing Interests Statement}

The authors declare that there are no competing or potential conflicts of interest.

\section{References}

Al-Watan

Voice.

(2012).

Abandoned

children.

Retrieved

from http://www.alwatanvoice.com/arabic/news/2012/07/07/294903.html

Andon, I. (2014). Foundling and abandoned children in Palestine: reality and challenges. Conference, Al-Quds University, main campus, Abu Dies, April 14. Retrieved from https://www.alquds.edu/ar/news-ar/138308-.html 
Arab Human Development Report. (2009). Challenges to human security in the Arab countries. New York: United Nations Development Program. Retrieved from http://hdr.undp.org/sites/default/files/hdr2009-arabic.pdf

Awwad, T. (2014). Foundling and abandoned children in Palestine: the Christian point of view. Conference, Al-Quds University, main campus, Abu Dies, April 14. Retrieved from https://www.alquds.edu/ar/news-ar/138308-.html

Ball, A. (1994). And now my soul is hardened: abandoned children in Soviet Russia 1918-1930. Berkeley: University of California Press.

Banat, B. (2014). Sense of community among Palestinians. Asian Journal of Social Sciences \& Humanities, 3(4), 197-207. Retrieved from http://www.ajssh.leena-luna.co.jp/AJSSHPDFs/Vol.3(4)/AJSSH2014(3.4-19).pdf

Barakat, H. (1993). The Arab World: society, culture, and state. Berkeley: University of California Press.

Black, C. (2010). Understanding the pain of abandonment: living with repeated abandonment experiences creates toxic shame: the many faces of addiction. Retrieved from https://www.psychologytoday.com/us/blog/the-many-faces-addiction/201006/understanding-the-pain-aband onment

Blackie, D. (2014). Fact sheet on child abandonment research in South Africa. South Africa: National Adoption Coalition. Retrieved from http://146.141.12.21/bitstream/handle/10539/17064/ Deirdre\%20Blackie\%20Masters\%20Thesis\%20March\%202014\%20Final\%20Submission.pdf?sequence=1 \&isAllowed $=\mathrm{y}$

Boswell, J. (1998). The kindness of a stranger: the abandonment of children in Western Cape from late antiquity to the renaissance. New York: University of Chicago press.

Crèche Institution. (2015). Foundling and abandoned children and abandoning mothers' primary data. Bethlehem.

Del Col, L. (1988). The life of the industrial worker in nineteenth century England. Morgantown: West Virginia University

Fuchs, R., \& McBride-Schreiner, S. (2014). Foundling and abandoned children. Oxford Bibliographies. https://dx.doi.org/10.1093/obo/9780199791231-0075

Helton, L., \& Jackson, M. (1997). Social work practice with families: a diversity model. Boston: Allyn and Bacon.

Huang, C-C., Barreda, P., Mendoza, V., Guzman, L., \& Gilbert, P. (2004). A comparative analysis of abandoned street children and formerly abandoned street children in La Paz, Bolivia. Archive Disease in Childhood, 89(9), 821-826.

Idees, Y. (2014). Foundling and abandoned children in Palestine: the Islam point of view. Conference, Al-Quds University, main campus, Abu Dies, April 14. Retrieved from https://www.alquds.edu/ar/news-ar/138308-.html

International Street Kinds-ISK. (2014). Statistics on abandoned children. Retrieved from http://www.internationalstreetkids.com/statistics.php

Kgole, M. (2007). The needs of caregivers of abandoned children (Master Thesis, South Africa: University of Pretoria).

Nelson, C., Fox, N., \& Zeanah, C. (2014). Romania's abandoned children deprivation, brain development, and the struggle for recovery. Cambridge: Harvard University Press.

Palestinian Central Bureau of Statistics. (2017). Population, housing and establishment census. Ramallah.

Panter-Brick, C., \& Smith, M. (2000). Abandoned children. Journal of Biosocial Science, 34(3), 426-428. https://doi.org/10.1017/S0021932002224256

Ransel, D. (2002). Abandoned children. Journal of Interdisciplinary History, 32(3), 449-450. Retrieved from http://www.jstor.org/stable/3656221

SOS Children's villages International. (2012). Facts and figures. Bethlehem.

Stativă, E., Anghelescu, C., Mitulescu, R., Nanu, M., \& Stanciu, N. (2005). The situation of child abandonment in

$\mathrm{UNICEF}$

Romania.

Retrieved

from https://www.unicef.org/ceecis/GDD_2005_Romania_Child_abandonment.pdf

The Holy Quran, Al-Ahzab. 
The Holy Quran, Al-Isra.

United Nations General Assembly. (1989). Convention on the rights of the child A/RES/44/25. Retrieved from http://www.un.org/ga/search/view_doc.asp?symbol=A/RES/44/25

Van Wyden, G. (2014). Mother abandonment and the effects on the child. Retrieved from http://www.livestrong.com/article/159897-mother-abandonment-the-effects-on-the-child/

Whetten, K., Ostermann, J., Whetten, R., Pence, B., O'Donnell, K., Messer, L., \& Thielman, N. (2009). A comparison of the wellbeing of orphans and abandoned children ages 6-12 in Institutional and community-based care settings in 5 less wealthy nations. PLoS ONE, 4(12), 8169. https://doi.org/10.1371/journal.pone.0008169

World Health Organization [WHO]. (2013). Global and regional estimates of violence against women: prevalence and health effects of intimate partner violence and non-partner sexual violence. Geneva: WHO Press. Retrieved from https://apps.who.int/iris/bitstream/handle/10665/85239/9789241564625_eng.pdf;jsessionid= DC092861AA6E7293476DDCF6AA846D67?sequence=1

\section{Copyrights}

Copyright for this article is retained by the author(s), with first publication rights granted to the journal.

This is an open-access article distributed under the terms and conditions of the Creative Commons Attribution license (http://creativecommons.org/licenses/by/4.0/). 